\title{
Simplified method of applying loads to flat slab floor structural model
}

\author{
Maciej Tomasz Solarczyk ${ }^{1, *}$, and Andrzej Ambroziak ${ }^{1}$ \\ ${ }^{1}$ Gdańsk University of Technology, Faculty of Civil and Environmental Engineering, \\ Narutowicza 11/12, 80-233 Gdańsk, Poland
}

\begin{abstract}
The article analyses the impact of the live load position on the surface of a reinforced concrete flat slab floor of $32.0 \mathrm{~m} \times 28.8 \mathrm{~m}$. Four variants of a live load position are investigated: located on the entire concrete slab, set in a chessboard pattern, applied by bands and imposed separately in each of the slab panels. Conclusions are drawn upon differences in bending moments, the time of calculation and the size of output files. The problems in the interpretation of results are presented too. A procedure is presented to model the reinforced concrete structures in computational programs. The recommendations of the Eurocodes are presented regarding to load combinations in the Ultimate Limit State (ULS). Convergence analysis of the finite element mesh is carried out to verify the obtained results. The law status on the implementation of the Building Information Modelling (BIM) technology in Poland points out significant time savings in the application of this technology.
\end{abstract}

\section{Introduction}

Structural design is generally based on virtual mapping of a real object. The designer is supported by a number of computational tools to complete the task. A widespread automation of design works makes it available for the engineers with little experience. It should be emphasized that the results of numerical analysis should be permanently and critically assessed by the designer after computations. While a designer is not experienced the assessment may not be sufficiently reliable.

In the design process the task of a structural designer is to determine the static model and the load layout, finally, to verify the results. These tasks include: definition of the structure (dimensions, types of finite elements, material data, support types), determining of finite element mesh (FE), load application, load combination statement, verification of the FE mesh and the final internal forces. These steps are necessary for the designer of reinforced concrete structures to determine the required reinforcement due to an entirety of Ultimate Limit States (ULS) and Serviceability Limit States (SLS).

Each of the modelling steps is important due to real structural analysis. The most difficult task is a proper representation of subsequent elements included in structural system (columns, beams, slabs, etc.) together with their assembly. There is a number of modelling possibilities,

\footnotetext{
*Corresponding author: maciej.solarczyk@pg.edu.pl
} 
each one detecting advantages and disadvantages. Some important information about slabbeam structures is given in articles [1,2] and in the book [3].

It should be emphasized that even a structure accurately mapped in a computational model but subjected incorrectly defined loads will not be analysed properly. While the loads are overestimated the designed structure does not pose a threat to the safety and life of people at operation but it is uneconomic. When the loads are underestimated the result may trigger a structural disaster, to possibly bring fatalities.

The article assesses the impact of the load action to the structural response, i.e. internal forces. The factors affecting the design efficiency are the calculation time, simplicity in the interpretation, accuracy of the solution.

\section{Combinations of actions in ULS in terms of Eurocode}

Due to Ultimate Limit States, the design load values should be applied, forming possible combinations of actions. According to the standard [4] the partial critical factors $\gamma_{G}=1.35$ and $\gamma_{Q}=1.5$ are assumed for permanent and variable actions, respectively.

According to the principle given in 5.1.3 (1)P in Eurocode 2 [5]: In considering the combinations of actions (...) the relevant cases shall be considered to enable the critical design conditions to be established at all sections, with the structure or part the structure considered.

In addition, the note to point 5.1.3 (1)P in [5] states: (...) The following simplified load arrangements are recommended for buildings:

(a) Alternate spans carrying the design variable and permanent load (...); other spans carrying only the design permanent load (...) and

(b) Any two adjacent spans carrying the design variable and permanent loads (...). All others spans carrying only the design permanent load (...).

It should be noted that standard recommendations [5] do not always converge the principles of structural mechanics. If the recommendation from subsection (a) is intended to the determine the maximum bending moments in the span, the subsection (b) does not results in a predetermined maximum moment at the support. While determining the influence line of bending moment at the support of a continuous beam, two adjacent spans and every second subsequent span should be loaded with alternating load. Nevertheless, the difference in the results is considered insignificant.

\section{Description of flat slab floor structural model}

The investigated flat slab floor is a component of an office building. One of the storeys has been separated to form a numerical model. The reinforced concrete slab of $20 \mathrm{~cm}$ thickness is made of $\mathrm{C} 20 / 25$ concrete. The height of the storey is $3.0 \mathrm{~m}$. The slab supports are reinforced concrete columns $30 \mathrm{~cm} \times 30 \mathrm{~cm}$ made of $\mathrm{C} 20 / 25$ concrete. The numerical model assumes that the concrete columns are situated above and below the considered slab. In the x-direction the slab shows five spans of $6.4 \mathrm{~m}$, while in the y-direction there are four spans of $7.2 \mathrm{~m}$. The assumed actions are: dead structural load (taken from the software), complementary dead load of a finished floor, equal $2 \mathrm{kN} / \mathrm{m}^{2}$ (estimation) and imposed uniformly distributed load equal $3.0 \mathrm{kN} / \mathrm{m}^{2}$. The value of imposed load is taken according to Tables 6.1 and 6.2 (see PN-EN 1991-1-1:2004 standard [6]). The B category of office areas are subjected to a load equal $3.0 \mathrm{kN} / \mathrm{m}^{2}$.

Computations were conducted by means of the Robot Structural Analysis Professional (RSAP) system, version 2015. The software is integrated with the graphically environment servicing for modelling, analysis and dimensioning of various structural element types. It 
provides: generating FEM meshes, performing calculations and verifying the results, dimensioning individual elements and preparing documentation of the project. There are national versions including national standards with design specifications, see $[7,8]$.

The calculations were carried out on computer with processor Intel Core i7 with RAM of 4,0 GB.

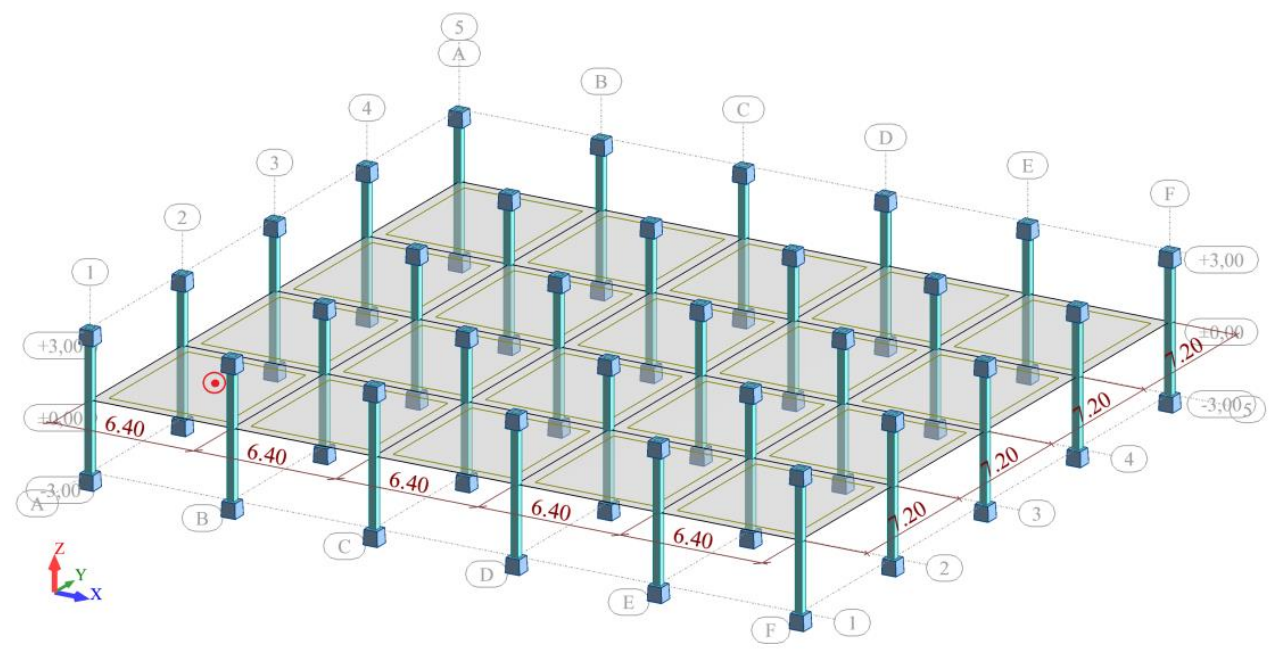

Fig. 1. Geometry of the analysed flat slab floor with the point designation in which the analysis of the results of internal forces is made.

For the sake of comparative analysis four variants were considered to locate the load on a slab-column structure:

1) variant 1 - live load located on an entire surface of the slab (no combinations for this type of load, thus an increase in the variable action partial factor by additional $25 \%-30 \%$ was assumed to obtain a global coefficient $\gamma_{Q}=1.9$ );

2) variant 2 - live load set in a chessboard pattern load (in this variant three combinations in the Ultimate Limit State are specified);

3) variant 3 - live load set by bands (three combinations are determined in ULS);

4) variant 4 - live load applied separately in each panel of slab (combinations in ULS are generated automatically by the RSAP program).

\section{Finite Element Mesh refinement}

An inherent step of the FEM computational procedure is a FE mesh convergence analysis in the RASAP case, described in detail in the books [7,8]. This is necessary check of the method correctness due to its approximate character. A characteristic point is chosen to check the convergence. Comparing the internal force values in a selected point the convergence of the solution is assessed with respect to mesh refinement.

In the worked case, the FE mesh was doubled to achieve satisfactory results. In the investigated model the mid-point of A-B and 1-2 section were taken into account for convergence check (see Fig. 1). The FE mesh was verified in numerically due to load variant 1. In the presented calculations $1 \%$ difference in bending moments is taken as a limit for the subdivision of FE mesh (due to a regular FE mesh and the simplified live load assessment in variant 1$)$. 
Table 1. Analysis of finite element mesh convergence.

\begin{tabular}{|c|c|c|c|}
\hline No. & Mesh density (size of FE) & $\mathbf{M}_{\mathbf{x x}}[\mathbf{k N m} / \mathbf{m}]$ & Difference [\%] \\
\hline 1. & $80 \mathrm{~cm} \times 80 \mathrm{~cm}$ & 33.30 & - \\
\hline 2. & $40 \mathrm{~cm} \times 40 \mathrm{~cm}$ & 34.02 & 2.16 \\
\hline 3. & $20 \mathrm{~cm} \times 20 \mathrm{~cm}$ & 34.66 & 1.88 \\
\hline 4. & $10 \mathrm{~cm} \times 10 \mathrm{~cm}$ & 34.86 & 0.58 \\
\hline
\end{tabular}

Table 2. Computation time and output file size under convergence of the FE mesh.

\begin{tabular}{|c|c|c|c|}
\hline No. & Mesh density (size of FE) & Time & Output file size \\
\hline 1. & $80 \mathrm{~cm} \times 80 \mathrm{~cm}$ & $5 \mathrm{~s}$ & $4.2 \mathrm{MB}$ \\
\hline 2. & $40 \mathrm{~cm} \times 40 \mathrm{~cm}$ & $20 \mathrm{~s}$ & $7.5 \mathrm{MB}$ \\
\hline 3. & $20 \mathrm{~cm} \times 20 \mathrm{~cm}$ & $2 \mathrm{~min}$ & $24.7 \mathrm{MB}$ \\
\hline 4. & $10 \mathrm{~cm} \times 10 \mathrm{~cm}$ & $25 \mathrm{~min}$ & $92.8 \mathrm{MB}$ \\
\hline
\end{tabular}

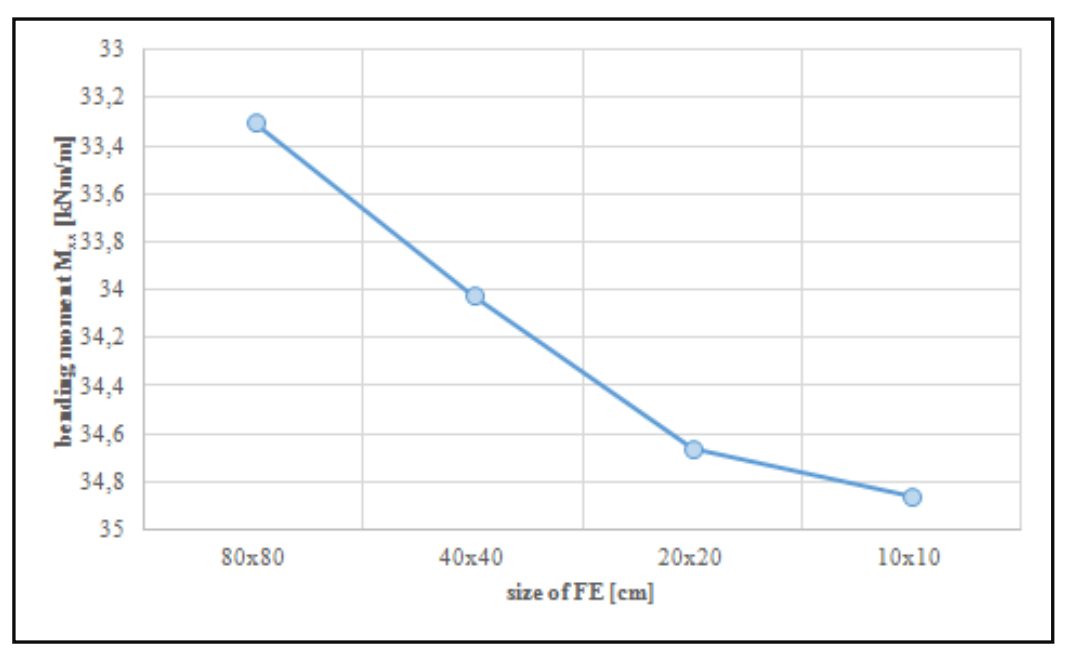

Fig. 2. Finite Elements mesh convergence.

The results in Tables 1 and 2 point out the FE size of $20 \mathrm{~cm} \times 20 \mathrm{~cm}$ to give satisfactory internal forces results, this mesh is accepted for final calculations. Additionally, this mesh density provides an acceptable calculation time equal 2 minutes and a reasonable output file size with calculation results (about $25 \mathrm{MB}$ ).

\section{Analysis of bending moments}

While the numerical calculations are performed a detailed comparison of bending moments for a concrete slab is done. Figs. 3-4 present a bending moment $\mathrm{M}_{\mathrm{xx}} \operatorname{map}[\mathrm{kNm} / \mathrm{m}]$ for the ULS. 


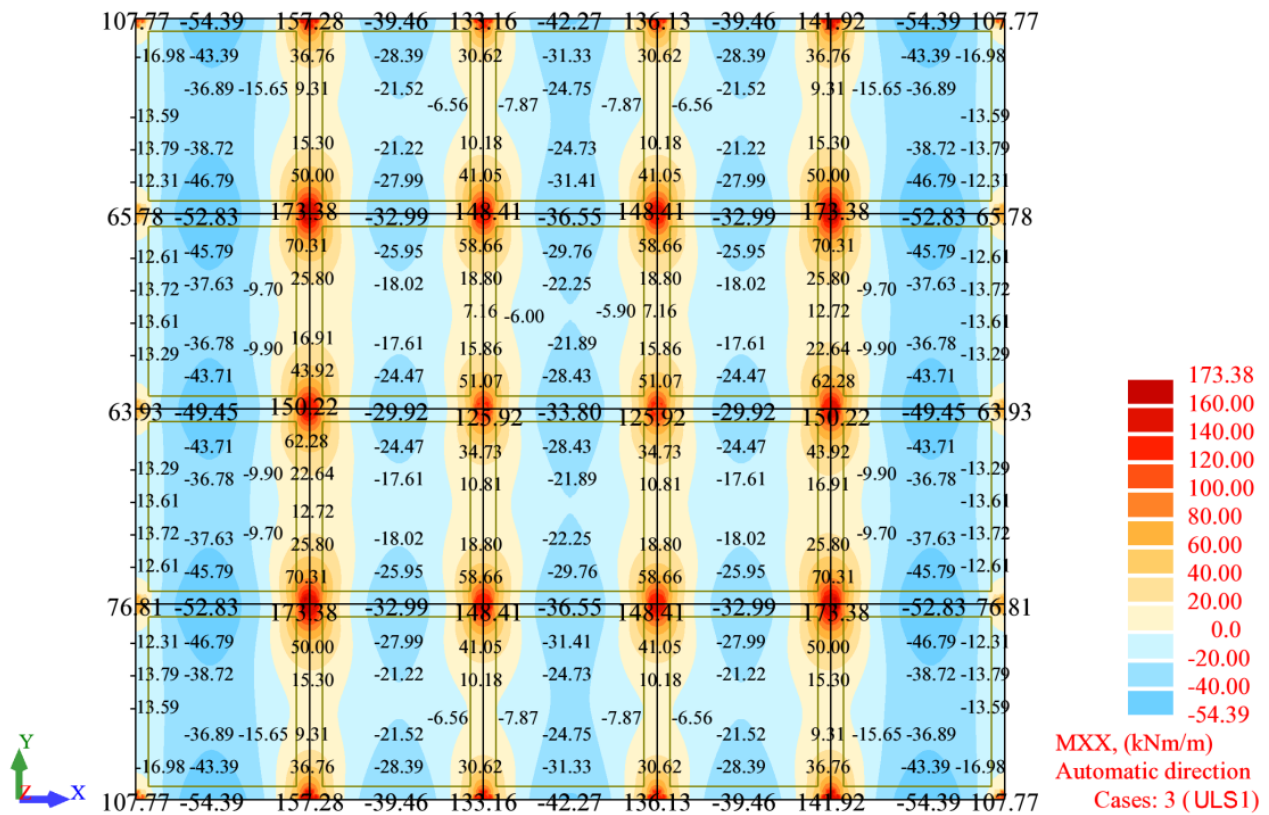

Fig. 3. Map of bending moment $\mathrm{M}_{\mathrm{xx}}-$ variant 1 for ULS1.

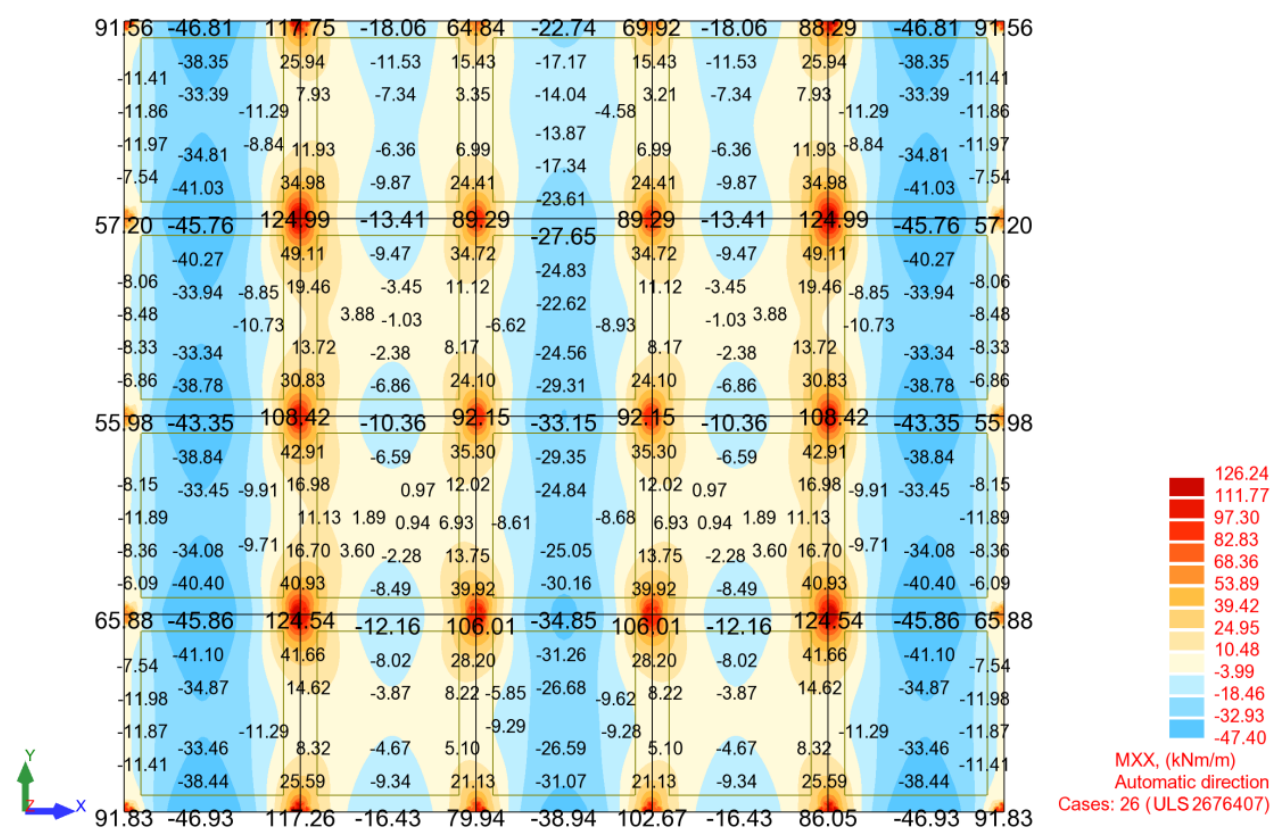

Fig. 4. Map of bending moment $\mathrm{M}_{\mathrm{xx}}$ - variant 4 for ULS $2676507 / 4194304$. 
Table 3. Results of bending moments - differences in results compared to the accurate solution (variant 4).

\begin{tabular}{|c|c|c|c|c|c|}
\hline No. & Variant of calculations & $\begin{array}{c}\mathbf{M}_{\mathbf{x x}} \\
{[\mathbf{k N m} / \mathbf{m}]}\end{array}$ & $\begin{array}{c}\text { Difference } \\
\mathbf{M}_{\mathbf{x x}}[\mathbf{\%}]\end{array}$ & $\begin{array}{c}\mathbf{M}_{\mathbf{y y}} \\
{[\mathbf{k N m} / \mathbf{m}]}\end{array}$ & $\begin{array}{c}\text { Difference } \\
\mathbf{M}_{\mathbf{y y}}[\mathbf{\%}]\end{array}$ \\
\hline 1. & variant 1 & 34.66 & 7.87 & 40.62 & 6.78 \\
\hline 2. & variant 2 & 32.34 & 0.65 & 37.98 & -1.43 \\
\hline 3. & variant 3 & 35.36 & 10.05 & 37.38 & -3.30 \\
\hline 4. & variant 4 & 32.13 & - & 38.44 & - \\
\hline
\end{tabular}

Table 4. The calculation time and the size of output files.

\begin{tabular}{|c|c|c|c|}
\hline No. & Variant of calculations & Time & File size \\
\hline 1. & variant 1 & $2 \min$ & $24.7 \mathrm{MB}$ \\
\hline 2. & variant 2 & $2 \min 30 \mathrm{~s}$ & $55.0 \mathrm{MB}$ \\
\hline 3. & variant 3 & $2 \min 30 \mathrm{~s}$ & $55.3 \mathrm{MB}$ \\
\hline 4. & variant 4 & $5 \min 50 \mathrm{~s}$ & $268.7 \mathrm{MB}$ \\
\hline
\end{tabular}

\section{Discussion}

The calculation results in variant 1 are safe, overestimating the bending moments $\mathrm{M}_{\mathrm{xx}}$ and $\mathrm{M}_{\mathrm{yy}}$ by about $7 \%$. It can therefore be concluded that the adopted global coefficient $\gamma_{Q}=1.9$ has been slightly scaled. The imposed live load applied in the chessboard pattern gives similar results for $\mathrm{M}_{\mathrm{xx}}(0.65 \%)$, it underestimates the bending moment $\mathrm{M}_{\mathrm{yy}}$ (by $1.43 \%$ ) as well as the load applied by bands $(3.30 \%)$ in the variant 3 .

The calculation time due to different loading variants is also compared. The calculation time for variants: 1, 2 and 3 is almost constant, equal to approx. 2 minutes. The calculations time for the variant 4 takes it higher - about 6 minutes. Additionally, the variant 4 results is a more time-consuming presentation in RSAP program, compared to others variants. The least size of output file is detected for the variant 1 , equal to $10 \%$ of variant 4 capacity.

The calculations for variant 1 may be acceptable for the ULS, however this variant underestimates the deflection values due to SLS. In the present calculations the problem of scratched concrete is neglected. Nevertheless, in real structural calculations the decrease of stiffness of the reinforced concrete structure after scratching must be taken into account.

The load application and CPU time of calculations to asses a given variant of numerical calculations of a structural model. An efficient loading pattern is a constant uniformly distributed load on a whole surface of a concrete slab. Applying a load on the slab structure with bands (variant 3 ) or on a chessboard (variant 2) pattern are slightly more time consuming but may be acceptable. Imposing a load to each slab panel separately (variant 4) is hard and time-consuming, thus it is disqualified from practice.

From the viewpoint of numerical correctness the choice of a finite element mesh size (convergence analysis) is more considerable than an accurate definition of imposed live loads.

An important factor to act upon the solution effectiveness is a direct interpretation of numerical results. Live load applied on an entire slab surface makes a single load combination thus no mistake occurs here. The extreme internal forces due to chessboard and band load patterns appropriate number of combinations of actions exists. Extreme bending moments in support areas can be assessed from the combination with the loads added from both 
chessboards or bands patterns, whereas in the span area for separate chessboards or bands. It is quite complicated in this respect to interpret the results for the load applied separately in each slab panels. In this case tedious and hard investigation occurs for the values and location of maximum internal forces distribution, because the combinations in this variant are generated automatically by the RSAP program.

Due to the simplified method of deflection calculation (e.g. used the formulas given in paragraph 16.5.1 in [9]) the problem arises to determine the value of the $\alpha_{M}$ coefficient depending on the shape of the bending moment diagram. For the most commonly considered cases of continuously loaded components with bending moments at the ends of the span (according to Fig. 16.4 d) in [9]) it is necessary to determine the values of bending moments at the edges of the element from the ultimate combination of actions for the maximum moment in the span. Thus it can be problematic to consider the results from the variant 4 with a load applied in each panel separately.

Determination of internal forces in a structural model is necessary for reinforcement design. In reinforced concrete structures the amount of required reinforcement is specified under ULS and SLS combinations. The designer of reinforcement deals with the economics of the solution (approximation of the adopted reinforcement to the necessary due to structural calculations) and by facilitating the execution of reinforcement skeleton on the construction site. For this purpose, the designer should select the diameters, spacing and dimensions of reinforcement properly. The calculated reinforcement is almost greater than (or rarely equal to) the reinforcement adopted on construction drawings. In a majority of cases there is an additional load capacity reserve of reinforced concrete structures. Thus it can be concluded that slight differences in the results of internal forces obtained from the variants (precisely and approximate) of imposed loads can be negligible from a practical point of view.

In addition, it is noticeable the challenging architectural ideas corresponding to novel, slender structures trigger the Serviceability Limit State (deflection or scratch) as decisive. In order to meet these requirements, the designer must apply additional reinforcement to the structure raising the load bearing capacity again.

Finally, in the design process of flat slab floor it is a key issue to assure the punching resistance. Punching strength is a critical point in flat slabs design due to the lack of its theoretical description, empirical code-based formulations are still the most widespread to deal with the slab-column connections. Recommendation in point 5.6.1 of the standard [10] says: The degree of longitudinal reinforcement of elements checked for puncture (...) cannot be less than $0.5 \%$ in both directions. According to this requirement, the designer of flat slab floor has an additional reserve of load bearing capacity, thus possible differences may be omitted between the exact and simplified determination of internal forces out of analysed loading variants.

\section{Conclusions}

Nowadays the building industry in Poland tends to decrease time and costs allocated to structural design. The economic account becomes dominant in the buildings engineering process. The analysis of entire 3D structures becomes a widespread design practice, instead of a selected research upon e.g. a selected storey only.

A three-dimensional model was applied in the stadium structure in Gdansk for the European Football Championship in 2012 [11] - according to the designer, this 3D solution reduced the design time of the facility by as much as $85 \%$. In accordance with the European Parliament and Council Directives adopted in 2014: classic [12] and sectoral [13] - Building Information Modelling (BIM) technology should be implemented in the public construction process by all member states of the European Union. Poland introduced the directives in the 
act [14]. Consequently, all public investments must implemented the BIM technology, allowing for design based on 3D models.

The investigation performed in the paper can be perspective regarding the application of loads to the flat slab floor structural model. The proposed simplification is intendent to reduce design errors, save the CPU time and make a more comprehensive result analysis.

It can be concluded that in the case of Ultimate Limit State calculations the most effective way of applying loads to flat slab floor structural model is variant 1 (live load located on an entire surface of the slab with variable action partial factor $\gamma_{Q}=1.9$ ). It allows to save the computational time, leads to a small size of output file and provides a straightforward and direct interpretation of numerical results.

\section{References}

1. P. Kossakowski, Inżynierski problem komputerowego modelowania pracy żelbetowej płyty dwuprzęsłowej z uwzględnieniem sprężystej podatności belki, Przegląd Budowlany, 10, 19-24 (2012)

2. P. Kossakowski, Uwzględnienie wpływu sprężystej podatności belek w numerycznym modelowaniu stropów żelbetowych, Przegląd Budowlany, 11, 24-31 (2014)

3. W. Starosolski, Komputerowe modelowanie betonowych ustrojów inżynierskich wybrane zagadnienia, edition V, volumes 1 and 2, Gliwice: Wydawnictwo Politechniki Śląskiej (2013)

4. PN-EN 1990:2004, Eurocode - Basis of structural design

5. PN-EN 1992-1-1:2008, Eurocode 2: Design of concrete structures. Part 1-1: General rules and rules for buildings

6. PN-EN 1991-1-1:2004, Eurocode 1: Actions on structures. Part 1-1: General actions Densities, self-weight, imposed loads for buildings

7. A. Ambroziak, P. Kłosowski, Autodesk Robot Strutural Analysis Podstawy Obliczeń, Gdańsk: Wydawnictwo Politechniki Gdańskiej (2013)

8. A. Ambroziak, P. Kłosowski, Autodesk Robot Structural Analysis Wymiarowanie konstrukcji stalowych i żelbetowych, Gdańsk: Wydawnictwo Politechniki Gdańskiej (2016)

9. M. Knauff, Obliczanie konstrukcji żelbetowych wedtug Eurokodu 2, Warszawa: Wydawnictwo Naukowe PWN (2012)

10. PN-B 03264:2002, Konstrukcje betonowe, żelbetowe i sprężone. Obliczenia statyczne i wymiarowanie

11. R. Wojdak, Nietypowe autorskie konstrukcje budowlane. Stadion piłkarski na EURO 2012 w Gdańsku i inne obiekty, Gdańsk: Wydawnictwo Politechniki Gdańskiej (2010)

12. Directive of the European Parliament and of the Council 2014/24/EU of 26 February 2014 on public procurement and repealing Directive 2004/18/EC

13. Directive 2014/25/EU of the European Parliament and of the Council of 26 February 2014 on procurement by entities operating in the water, energy, transport and postal services sectors and repealing Directive 2004/17/EC

14. Ustawa z dnia 22 czerwca 2016 r. o zmianie ustawy - Prawo zamówień publicznych oraz niektórych innych ustaw, Dz.U. 2016 poz. 1020 